\title{
Role of calcium in the regulation of theca cell androstenedione production in the domestic hen
}

\author{
J. M. Levorse, J. L. Tilly and A. L. Johnson \\ Department of Animal Sciences, Rutgers, The State University of New Jersey, New Brunswick, \\ NJ 08903, USA
}

\begin{abstract}
Summary. Theca cells were collected from the second largest preovulatory follicle. Chelation of extracellular calcium with EGTA attenuated LH (10 ng)-induced androstenedione production by theca cells, and this effect was more pronounced in calciumdeficient than in calcium-replete incubation medium. Incubation of theca cells with steroidogenic agonists in the presence of the calcium channel blocker verapamil $(100 \mu \mathrm{M})$ suppressed androstenedione production stimulated by LH (a $57 \%$ decrease), the adenylate cyclase activator forskolin (a $59 \%$ decrease) and the cyclic adenosine monophosphate (cAMP) analog 8-bromo-cAMP (a 61\% decrease). Furthermore, 3,4,5-trimethoxybenzoic acid 8-(diethylamino)octyl ester (TMB-8), a putative inhibitor of intracellular calcium mobilization, suppressed LH-induced androstenedione production in a dose-dependent fashion.

The calmodulin inhibitors trifluoperazine $(100 \mu \mathrm{M})$ and R24571 $(50 \mu \mathrm{M})$ inhibited androstenedione production stimulated by hormonal (LH) and non-hormonal (forskolin, 8-bromo-cAMP) agonists (decreases ranging from 76 to $98 \%$ ). While increasing the intracellular calcium ion concentrations with the calcium ionophore A23187 did not affect basal concentrations of androstenedione, treatment of $\mathrm{LH}$-stimulated cells with the ionophore caused dose-dependent inhibition of androstenedione production; these effects were enhanced by coincubation with phorbol 12-myristate 13-acetate (a known activator of protein kinase $\mathrm{C}$ ). We conclude that the mobilization of calcium is critical for agonist-stimulated steroidogenesis in hen theca cells, apparently requiring the interaction of calcium with its binding protein, calmodulin. Furthermore, increased cytosolic calcium concentrations may be involved in the suppression of androstenedione production, possibly as a result of an interaction with protein kinase $\mathrm{C}$.
\end{abstract}

Keywords: androstenedione; calcium; calmodulin; hen; ovary; theca

\section{Introduction}

Several putative second messenger pathways, aside from the well-characterized adenylate cyclase/ cyclic adenosine monophosphate (cAMP) system, have been identified in avian ovarian granulosa cells which may mediate the actions of hormones on cellular function. The diacylglycerol/protein kinase $\mathrm{C}$ system and arachidonic acid may be important modulators of cAMP-mediated granulosa cell steroidogenesis in the domestic hen (Tilly \& Johnson, 1988, 1989a; Asem \& Tsang, 1989a, Johnson \& Tilly, 1990). A possible role for the calcium/calmodulin system in the regulation of hen granulosa cell steroid production has also been discussed (Asem \& Hertelendy, 1986a, b, 1987; Asem et al., 1987; Johnson, 1990).

However, the regulatory mechanisms which control steroid output from the theca layer of hen preovulatory follicles have not been clearly defined. Recent studies of hen theca cell function have shown that production of androstenedione, the predominant steroid synthesized by hen theca cells, 
can be stimulated via activation of the adenylate cyclase-cAMP second messenger pathway (Robinson \& Etches, 1986; Marrone \& Asem, 1988; Tilly \& Johnson, 1989b). Protein kinase C and arachidonic acid also regulate both basal and gonadotrophin-stimulated androstenedione production from dispersed theca cells (Tilly \& Johnson, 1989b; Johnson et al., 1991). However, apart from a single report that extracellular calcium may be required for follicle-stimulating hormone (FSH)-induced oestradiol production in hen theca cells (Onagbesan \& Peddie, 1989), we know of no published studies on the role of calcium and/or calmodulin in the control of theca androgen biosynthesis. The purpose of the present studies was to examine the role of calcium and the calmodulin system in hen theca cell steroidogenesis.

\title{
Materials and Methods
}

\begin{abstract}
Animals. Single-comb White Leghorn hens (Avian Services, Frenchtown, NJ, USA: and Moyer's Hatchery, Quakertown, PA, USA), 30-50 weeks of age and laying regular sequences of 4-6 eggs, were used. Birds were housed

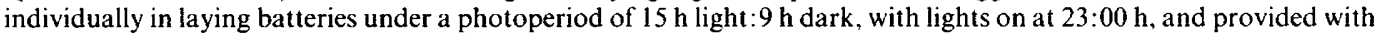
free access to feed (Agway Layer Mash, Agway, Inc., Bordentown, NJ, USA) and water. Individual laying records were maintained daily by monitoring the time of oviposition. The estimated time of ovulation was determined in individual hens from previous laying records and by digital palpation on the day of an experiment. Hens were killed by cervical dislocation $17-16 \mathrm{~h}$ before the second or third ovulation of a sequence.
\end{abstract}

Reagents. Ovine LH (NIAMDD-oLH-23, National Hormone and Pituitary Program, Baltimore, MD, USA) was prepared from a stock solution in $0 \cdot 1 \mathrm{M}$ phosphate-buffered saline with $2 \%$ bovine serum albumin (BSA) (v:w). Eightbromo-cyclic-AMP (8-br-cAMP), 3-isobutyl-1-methylxanthine (IBMX), phorbol 12-myristate 13-acetate (PMA), A23187, 3,4,5-trimethoxybenzoic acid 8-(diethylamino)octyl ester (TMB-8), trifluoperazine (TFP), and verapamil were obtained from Sigma Chemical Co. (St Louis, MO, USA). The putative calmodulin blocker R2457I was purchased from Janssen Life Sciences Products (Piscataway, NJ, USA). Forskolin was from Calbiochem Corp. (San Diego, CA, USA), and [ethylenebis(oxyethylenenitrilo)]tetraacetic acid (EGTA) was obtained from Fisher Scientific (Fair Lawn, NJ, USA). Verapamil, PMA, and R24571 were prepared from stock solutions in 95\% ethanol, while A23187, TMB-8, TFP, forskolin, and IBMX were prepared from stock solutions in dimethylsulphoxide. In all instances, the vehicle (final concentration of $0.1 \%$ or less) had no effect on the measures examined (data not shown). Eight-br-cAMP was dissolved directly into the incubation medium before each experiment.

Incubations. On the day of an experiment, the second largest preovulatory follicle was collected from $2-5$ hens. The theca tissue was pooled and cells were isolated as previously described using $0 \cdot 3 \%$ collagenase digestion followed by enrichment through 50\% continuous Percoll density gradient (Tilly \& Johnson, 1989b). Number of cells and viability (routinely $>90 \%$ ) were estimated with a haemocytometer and the trypan blue exclusion technique. Cells were equally apportioned into $12 \times 75 \mathrm{~mm}$ polypropylene incubation tubes (Sarstedt, Princeton, NJ, USA) to a final concentration of $2 \times 10^{5}$ cells per tube. Medium 199 with Hank's salts (GIBCO, Grand Island, NY, USA), supplemented as described by Tilly \& Johnson (1988), was used in all experiments except those that required calcium-deficient medium (second part of Exp. 1; see below). For those experiments a calcium-deficient Hank's balanced salts solution containing $0.1 \%$ BSA was utilized. In all experiments, cells were incubated in a total volume of $0.5 \mathrm{ml}$ for $4 \mathrm{~h}$ at $39^{\circ} \mathrm{C}$ under ambient air.

Experiments. Experiment 1 was performed to evaluate the role of extracellular calcium in steroid production. Theca cells were incubated in calcium-replete ( $1.5 \mathrm{~mm}$ calcium) medium with EGTA $(0,0 \cdot 03,0 \cdot 1,0 \cdot 3,1$ or $3 \mathrm{mM})$ in the absence or presence of $10 \mathrm{ng} \mathrm{LH}$ to stimulate androstenedione production. This experiment was then repeated using calcium-deficient (essentially $0 \mathrm{~mm}$ calcium) medium. After incubation, cells plus media were frozen at $-70^{\circ} \mathrm{C}$, thawed and assayed for androstenedione content.

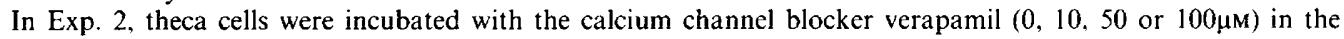
absence or presence of LH $(10 \mathrm{ng})$, forskolin $(1 \mu \mathrm{M})+0 \cdot 1 \mathrm{mM} \mathrm{IBMX}$, or 8-br-cAMP $(1 \mathrm{mM})$. Forskolin and 8-br-cAMP were used to determine the effects of activating the cAMP second messenger system at sites distal to the LH receptor. Theca cells were also treated with the putative blocker of intracellular calcium mobilization TMB- $8(0,1,10,100$ or $250 \mu \mathrm{M}$ ) in the absence or presence of $10 \mathrm{ng} \mathrm{LH}(\operatorname{Exp} .3)$. After a 4-h incubation and freeze-thawing. cell-plus-medium content of androstenedione was determined.

To evaluate the role of calmodulin in theca cell steroid production, cells were treated with the putative calmodulin inhibitors TFP $(0,01,1,10$ or $100 \mu \mathrm{M})$ or R24571 $(0,1,5,10$ or $50 \mu \mathrm{M})($ Exp. 4). These incubations were each conducted in the absence or presence of LH $(10 \mathrm{ng})$, forskolin $(1 \mu \mathrm{M})+0.1 \mathrm{mM}$ IBMX, or 8-br-cAMP (lmM). At the end of the 4-h incubation, cells plus media were frozen at $-70^{\circ} \mathrm{C}$ until assayed for androstenedione concentrations.

A final set of experiments was conducted to determine the effects of calcium mobilization on steroid production (Exp. 5). Basal and LH (10 ng)-stimulated androstenedione production were evaluated following treatment of theca cells with the calcium ionophore A23187 $(0,0 \cdot 05,0 \cdot 1,0 \cdot 5,1$ or $2 \mu \mathrm{M})$ in the absence or presence of PMA (162nM). Cells plus media were frozen at $-70^{\circ} \mathrm{C}$ after incubation until assayed for androstenedione content. 
Radioimmunoassays. Androstenedione (cell-plus-medium content) was measured, without extraction, as previously described (Tilly \& Johnson, 1989b). The sensitivity of the assay is $10 \mathrm{pg}$ and the intra- and interassay coefficients of variation were $<15 \%$.

Statistical analysis. All data presented represent the mean \pm standard error of the mean (s.e.m.) of results from 3 or 4 replicate incubations. Because of differences in basal and agonist-stimulated steroid concentrations among the replicate incubations, data were transformed to a percentage change relative to respective controls. Means were analysed by a one-way analysis of variance, and significant effects $(P<0.05)$ were determined by the Newman-Keuls multiple range test using the HSD Statistical Analysis Program (Human Systems Dynamics, Northridge, CA, USA).

\section{Results}

\section{Experiment 1: role of extracellular calcium}

Incubation of theca cells with EGTA in calcium-replete medium had no effect on basal steroid production $\left(P>0 \cdot 10 ; 0.17 \pm 0.01 \mathrm{ng} / 2 \times 10^{5}\right.$ cells) but inhibited LH-induced androstenedione production at the highest concentration $($ a $57.1 \pm 1.3 \%$ decrease at $3 \mathrm{~mm}$ EGTA; $P<0.001)$ (Fig. la). While LH-stimulated androstenedione production was not different in calcium-replete vs. calcium-deficient medium $\left(8.66 \pm 4.00\right.$ vs. $10.35 \pm 2.14 \mathrm{ng} / 2 \times 10^{5}$ cells, respectively) all concentrations of EGTA attenuated the steroidogenic response of theca cells to LH in calciumdeficient medium (maximal inhibition of $72 \cdot 7 \pm 12 \cdot 3 \%$ observed at a concentration of 1 mM EGTA; $P<0.001)$ (Fig. 1b). However, maximally effective doses of EGTA ( 1 and $3 \mathrm{~mm}$ ) did not reduce LHstimulated androstenedione concentrations to those of cells incubated in the absence of $\mathbf{L H}$ $\left(2.6 \pm 1.6\right.$ vs. $0.60 \pm 0.12 \mathrm{ng} / 2 \times 10^{5}$ cells, respectively; $\left.P<0.05\right)$.

(a)

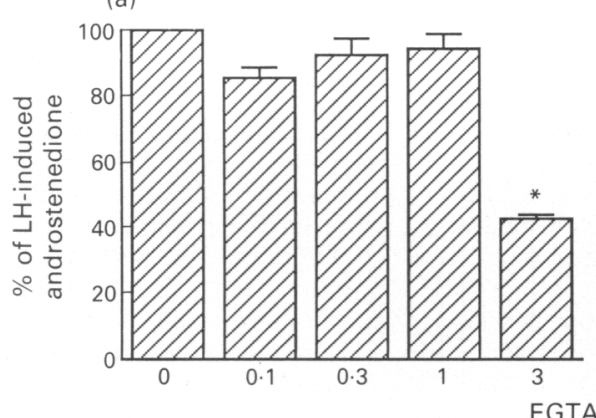

(b)

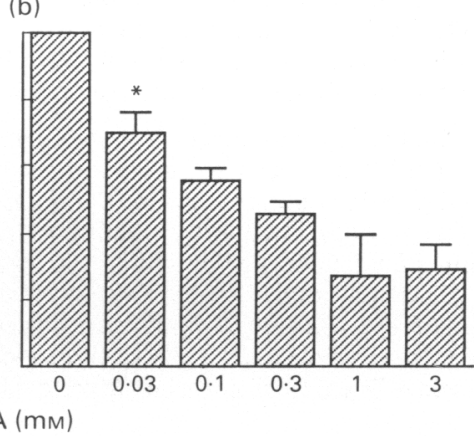

Fig. 1. Effects of EGTA on LH (10 ng)-stimulated androstenedione production from hen theca cells. Cells $\left(2 \times 10^{5}\right)$ were collected from the second largest preovulatory follicle and incubated in calcium-replete (a) or calcium-deficient (b) medium. Results represent the mean \pm s.e.m. of data from 3 replicate incubations. ${ }^{*}$ Denotes lowest dose at which inhibition is significant compared with the absence of EGTA $(P<0.05)$.

\section{Experiment 2: effects of blocking calcium channels}

The putative calcium channel blocker verapamil had no effect on basal androstenedione production ( $P>0.05$; data not shown), but caused a dose-dependent suppression of $\mathrm{LH}$-induced steroid production with a maximum inhibition of $57 \cdot 3 \pm 2 \cdot 1 \%$ at a dose of $100 \mu \mathrm{M}(P<0.001$; Fig. 2). Similar effects of $100 \mu \mathrm{M}$ verapamil were observed with forskolin (a $59 \cdot 4 \pm 2 \cdot 7 \%$ inhibition)and 8 -br-cAMP (a $60.6 \pm 2 \cdot 9 \%$ inhibition)-stimulated androstenedione production $(P<0 \cdot 001$; Fig. 2). 


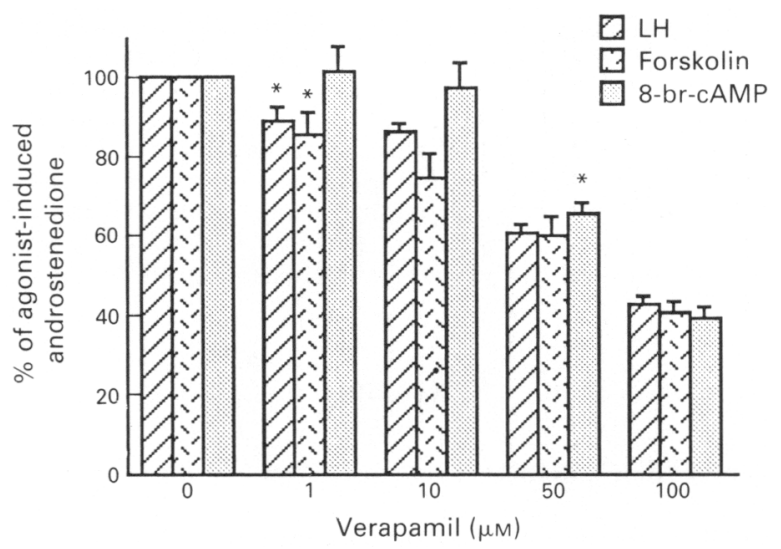

Fig. 2. Effects of the calcium channel blocker verapamil on androstenedione production by hen theca cells incubated in the presence of $\mathrm{LH}(10 \mathrm{ng})$, forskolin $(1 \mu \mathrm{M})+0 \cdot 1 \mathrm{mM}$ IBMX, or 8-br-cAMP ( $1 \mathrm{mM})$. Values represent the mean \pm s.e.m. of results from 3 replicate experiments. *Denotes the lowest dose at which androstenedione concentrations are significantly different from the absence of verapamil $(P<0.05)$.

\section{Experiment 3: effects of inhibiting calcium mobilization}

Incubation of cells with TMB-8 reduced LH-stimulated androstenedione production in a similar fashion, with essentially a complete suppression of the steroidogenic response to $\mathrm{LH}$ observed at a concentration of $250 \mu \mathrm{M}(P<0.001$; Fig. 3$)$.

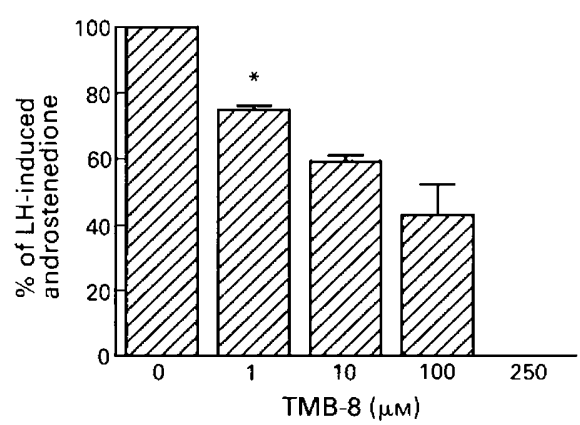

Fig. 3. Effects of TMB- 8 on $\mathrm{LH}$ (10 ng)-induced androstenedione production from hen theca cells incubated for $4 \mathrm{~h}$ (mean \pm s.e.m. of results from 3 replicate experiments). In the presence of $250 \mu \mathrm{M}$ TMB-8, androstenedione concentrations were undetectable in 2 of 3 incubations, and $0 \cdot 1 \%$ of $\mathrm{LH}$-stimulated in the third replicate experiment. ${ }^{*}$ Denotes the lowest dose at which inhibition is significant compared with the absence of TMB-8 $(P<0 \cdot 05)$.

\section{Experiment 4: role of calmodulin in steroidogenesis}

Trifluoperazine suppressed androstenedione production stimulated by $\mathrm{LH}$, forskolin and 8-bromo-cAMP, with virtually a complete inhibition of basal and agonist-stimulated steroidogenesis observed at a concentration of $100 \mu \mathrm{M}$ TFP $(P<0.001$; Fig. 4). The putative calmodulin inhibitor R24571 also caused a dose-dependent inhibition of LH-, forskolin-, and 8-br-cAMPinduced androstenedione production (Fig. 5). At a concentration of $50 \mu \mathrm{M}, \mathrm{R} 24571$ attenuated LH-stimulated androstenedione production by $76.2 \pm 12 \cdot 1 \% \quad(P=0.002$ vs. LH-stimulated $)$, 


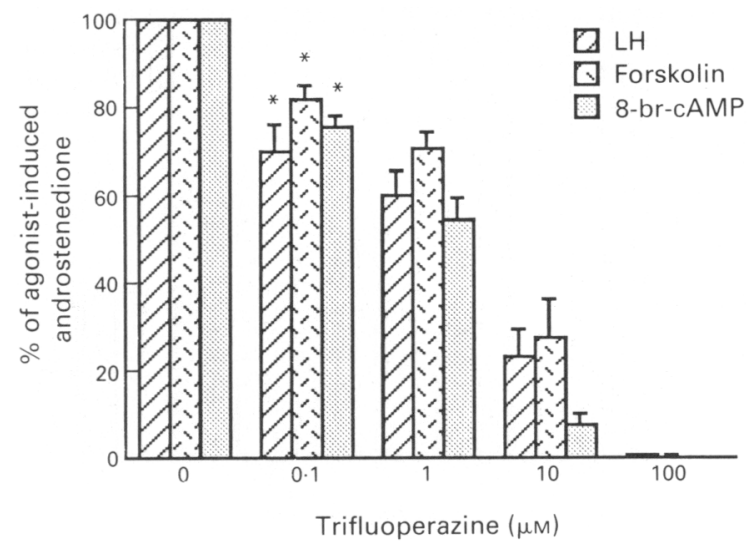

Fig. 4. Effects of trifluoperazine (TFP) on hen theca cell androstenedione production following incubation in the presence of $\mathrm{LH}(10 \mathrm{ng})$, forskolin $(1 \mu \mathrm{M})+0 \cdot 1 \mathrm{mM}$ IBMX, or 8-br-cAMP $(1 \mathrm{~mm})$. Values represent the mean \pm s.e.m. of results from 3 replicate incubations. *Denotes lowest dose at which androstenedione concentrations are significantly different from the absence of TFP $(P<0.05)$.

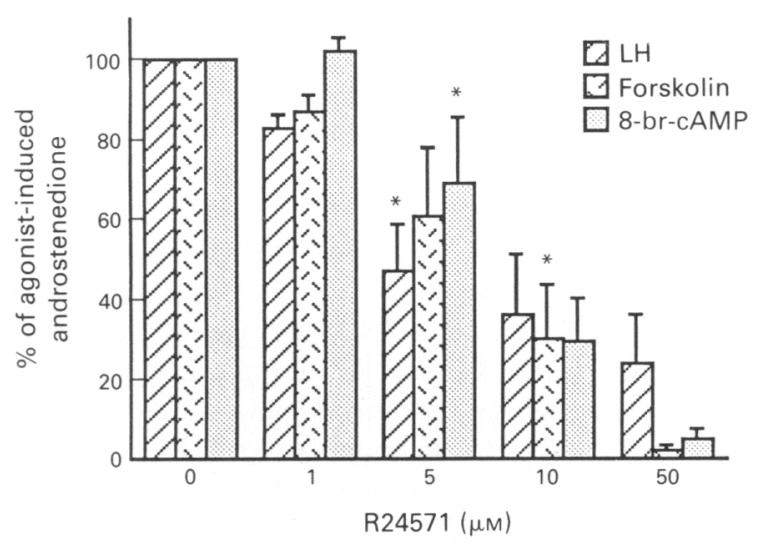

Fig. 5. Effects of the calmodulin inhibitor R24571 on androstenedione production from hen theca cells following stimulation by LH $(10 \mathrm{ng})$, forskolin $(1 \mu \mathrm{M})+0 \cdot 1 \mathrm{mM}$ IBMX, or 8 -brcAMP ( $1 \mathrm{mM})$. Data are the mean \pm s.e.m. of results from 3 replicate incubations. *Denotes lowest dose at which androstenedione concentrations are significantly different from the absence of $\mathrm{R} 24571(P<0.05)$.

whereas forskolin- and 8-br-cAMP-induced androstenedione output were inhibited by $98 \cdot 2 \pm 1 \cdot 7 \%$ and $95 \cdot 0 \pm 2 \cdot 5 \%$, respectively $(P<0 \cdot 001)$.

\section{Experiment 5: effects of the ionophore A23187}

The calcium ionophore A23187, at concentrations of up to $2 \mu \mathrm{M}$, had no effect on basal androstenedione production $\left(P>0.10\right.$; overall mean, $0.86 \pm 0.04 \mathrm{ng} / 2 \times 10^{5}$ cells $)$, but caused a dose-dependent inhibition of androstenedione production stimulated by LH (Fig. 6). A maximum inhibition of $61.2 \pm 2.7 \%$ was achieved at an ionophore concentration of $0.5 \mu \mathrm{M}$. The phorbol ester PMA (162nM) decreased androstenedione concentrations in the absence of A23187, and further 


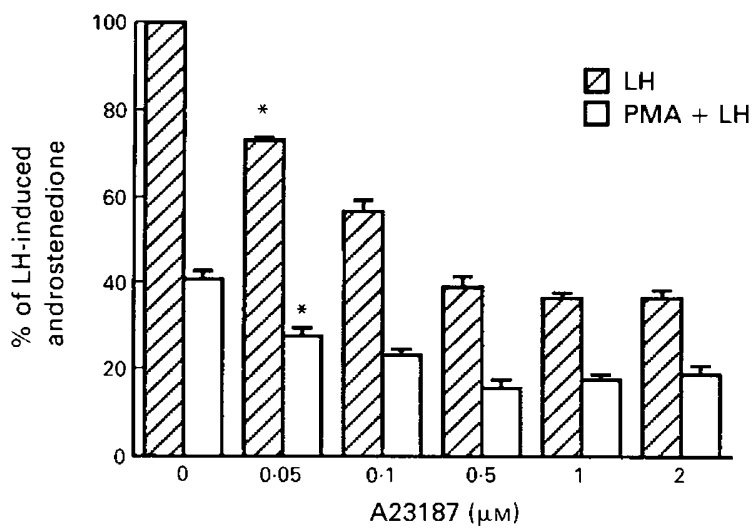

Fig. 6. $\mathrm{LH}(10 \mathrm{ng})$-induced androstenedione production from hen theca cells incubated with increasing concentrations of the calcium ionophore A23187, in the absence and presence of the tumor-promoting phorbol ester phorbol 12-myristate 13-acetate (PMA, 162nM). Data represent the mean \pm s.e.m. of results from 3 replicate incubations. ${ }^{*}$ Denotes lowest dose at which androstenedione concentrations are significantly different from those in the absence of A23187 $(P<0.05)$.

attenuated $\mathrm{LH}$-induced steroidogenesis at each dose of $\mathrm{A} 23187$, as compared with the ionophore alone $(P<0 \cdot 05)$.

\section{Discussion}

In hen ovary, the theca layer of maturing preovulatory follicles is the predominant source of androgens and oestrogens (Etches \& Duke, 1984). However, as the follicle matures to become the next to ovulate (e.g. the largest preovulatory follicle), the ability of the theca layer to produce steroids is dramatically reduced (Marrone \& Hertelendy, 1985; Robinson \& Etches, 1986), thereby necessitating the use of less mature follicles (i.e. the second largest) in studies concerning the control of steroidogenesis in theca cells. Although the role of calcium/calmodulin in regulating hen granulosa cell steroidogenesis has been extensively documented (Asem \& Hertelendy, 1986a, b, 1987; Asem et al., 1987; Johnson, 1990), very little is currently known concerning the role of calcium in regulating steroidogenesis in the adjacent theca layer.

In the present study, we found that extracellular calcium plays an important role in the control of theca cell steroidogenesis as shown by the ability of the calcium chelator EGTA to inhibit LH-induced androstenedione production. Although EGTA is not thought to enter the cell (Carnegie \& Tsang, 1984), its presence in calcium-deficient medium inhibits androstenedione production. It has been proposed that activation of calcium-dependent second messenger pathways causes calcium turnover in the cell; this process apparently involves both efflux of calcium from the cell as well as influx of calcium through voltage-regulated and receptor-controlled calcium channels (for review, see Exton, 1988). This mechanism may explain the inhibitory effects of EGTA on gonadotrophin-induced steroidogenesis in calcium-deficient medium. As calcium is exiting the cell, it is rapidly chelated by EGTA and therefore prevented from re-entering the cell. The fact that EGTA cannot suppress LH-stimulated androstenedione production to basal concentrations indicates that mobilization of intracellular calcium, without an influx of extracellular calcium, is sufficient to stimulate at least short-term androstenedione production.

The inhibitory effects of the calcium antagonist verapamil, a blocker of voltage-regulated calcium channels (Hinkle et al., 1988), also indicate that prevention of calcium entry into the cell has an inhibitory effect on androstenedione production induced by hormonal (LH) or pharmacologic 
(forskolin, 8-bromo-cAMP) agonists. These findings are consistent with those reported for LH-stimulated progesterone production in avian granulosa cells (Asem \& Hertelendy, 1986a). Although verapamil inhibited agonist-stimulated steroid production, it did not decrease androstenedione production to basal levels, a result similar to that observed following treatment with a maximally inhibitory dose of EGTA. While these compounds prevent calcium from entering the cell, androstenedione production can still apparently occur, albeit at reduced levels, following mobilization of intracellular calcium stores. The inhibitory effects of verapamil cannot be attributed to cytotoxicity since theca cells resumed androstenedione production following removal of verapamil from the incubation medium $\left(5 \cdot 2 \mathrm{ng} / 2 \times 10^{5}\right.$ cells as compared with $5 \cdot 1 \mathrm{ng} / 2 \times 10^{5}$ cells in vehicle-treated cells; data not shown).

Prevention of calcium mobilization within the cell by TMB-8, a compound previously shown to block calcium release from intracellular pools (Chiou \& Malagodi, 1975) and used as such in previous studies of steroidogenesis (Veldhuis et al., 1984; Asem \& Hertelendy, 1986a), also has inhibitory effects on androstenedione production stimulated by LH. TMB-8 completely attenuated LH-induced androstenedione production at the highest concentration utilized, even though extracellular calcium is not being prevented from entering the cell.

It has been proposed by Putney et al. (1989) that agonist-stimulated calcium mobilization causes an emptying of internal calcium stores which are then refilled by internalization of extracellular calcium. It is suggested that extracellular calcium is brought directly into intracellular calcium storage spaces without traversing the cytoplasm. If this is the case with hen theca cells, then prevention of intracellular calcium mobilization would effectively prevent an increase in cytoplasmic calcium concentrations. This may therefore explain the ability of TMB-8 to eliminate entirely androstenedione production stimulated by LH.

It is generally accepted that once calcium enters the cytoplasm it works by, among other things, binding to and activating the protein calmodulin (Exton, 1988). The calcium/calmodulin complex then interacts with other proteins or enzymes, resulting in various cellular responses. It appears that calcium may work, at least in part, via calmodulin in hen theca cells as evidenced by the effects of the two calmodulin inhibitors TFP and R24571, which reportedly act via an inhibition of calmodulin-dependent phosphodiesterase activity (Van Belle, 1981). Both calmodulin inhibitors were found to cause a dose-dependent attenuation of androstenedione production stimulated by LH, forskolin and 8-bromo-cAMP. The effects of R24571 and TFP are similar to those reported for granulosa cells from the rat (Carnegie \& Tsang, 1984), pig (Veldhuis et al., 1984) and hen (Asem $\&$ Hertelendy, 1986b). Of interest is that a TFP concentration of $100 \mu \mathrm{M}$, which has been previously used without cytotoxic effects in hen granulosa cells (Asem \& Hertelendy, 1986b), completely suppressed both agonist-stimulated (Fig. 5) and basal (data not shown) androstenedione production. Since TFP has also been shown to inhibit cholesterol side-chain cleavage activity-function (Asem \& Hertelendy, 1987), this ability to inhibit steroid production at two sites may account for the total elimination of androstenedione production by TFP.

The calcium ionophore A23187 has previously been shown to stimulate basal steroid production in granulosa cells of the rat (Carnegie \& Tsang, 1984; Tsang et al., 1989) and chicken (Tilly \& Johnson, 1988). Furthermore, we have also reported that A23187 has no effect on progesterone production in avian granulosa cells stimulated by LH (Tilly \& Johnson, 1988). In the present study, however, we found that A23187 had no effect on basal androgen production but reduced LHstimulated androstenedione concentrations by approximately $60 \%$ at the higher concentrations utilized. This finding may appear contradictory to results obtained from Exps 1-3, which indicated that calcium was apparently required for agonist-induced steroidogenesis. While the reasons for this apparent discrepancy are unclear at present, we would offer the following possible explanations. First, in the study by Onagbesan \& Peddie (1989), A23187 was reported to increase basal production of oestrone and oestradiol, possibly by enhancing the conversion of androgen substrates to oestrogens. If this is the case, increased concentrations of androstenedione within theca cells stimulated by the presence of LH may be more rapidly converted to oestrogen metabolites by 
cotreatment with A23187, thereby reducing the total amount of androstenedione measured following incubation. We have also recently shown that A23187 stimulates the release of endogenous arachidonic acid from theca cells (Johnson et al., 1991). Since arachidonic acid can inhibit androstenedione production in theca cells (Johnson et al., 1991), it is possible that the inhibitory action of calcium may be mediated via the release of arachidonic acid from membrane phospholipids.

Another possibility is that A23187 promotes an extended phase of increased cytoplasmic calcium concentrations, not necessarily mimicking the rapid rise and fall in calcium concentrations reported to occur in response to hormonal agonists (i.e. $\mathrm{LH}$ ) in avian ovarian cells (Asem et al., 1987). For instance, there appear to be two discrete pools of calcium within cells, one sensitive, the other insensitive, to the endogenous calcium-mobilizing second messenger inositol 1,4,5-trisphosphate; however, A23187 appears to mobilize calcium from both pools (Ghosh et al., 1990). Therefore, cytosolic calcium can approach millimolar concentrations in response to the ionophore. These supraphysiological concentrations of calcium may then have direct inhibitory effects on cellular function, as proposed by White et al. (1989).

Finally, it has been reported that protein kinase $\mathrm{C}$ may be translocated and thus activated by high concentrations of calcium in the absence of diacylglycerol (Ho et al., 1988). Therefore, the inhibitory effects of calcium mobilization induced by A23187 may also indirectly result from the activation of protein kinase $\mathrm{C}$, a mechanism we have previously reported to suppress LH-stimulated androgen production in hen theca cells (Tilly \& Johnson, 1989b). In addition, we observed an additive effect of incubating theca cells with A23187 and the protein kinase C inhibitor PMA. Since PMA alone is capable of reducing agonist-stimulated androstenedione production in hen theca cells by approximately 50\% (Tilly \& Johnson, 1989b), an additive inhibitory effect of A23187 on theca cell androstenedione output would be expected.

Our results indicate that calcium, of both extra- and intracellular sources, and calmodulin are important regulatory mediators of androgen production in hen theca cells. Furthermore, extended periods of increased cytoplasmic calcium (induced by A23187) may serve as a negative feedback mechanism to reduce steroid production via the acceleration of oestrogen production from androgen, activation of protein kinase $\mathrm{C}$ and/or alterations in cytoplasmic $\mathrm{pH}$. Therefore, as reported for hen granulosa cells, the calcium/calmodulin system apparently plays an important role in the regulation of steriodogenesis in hen theca cells.

We thank the National Hormone and Pituitary Program for ovine LH; and Ms C. Brown for excellent technical assistance. This study was supported by grants from the USDA (88-37242-4013 and 90-37240-5510), the Charles and Johanna Busch Memorial Fund at Rutgers, the State University of New Jersey, and the New Jersey Agricultural Experiment Station (publication D-06107-01-90).

\section{References}

Asem, E.K. \& Hertelendy, F. (1986a) Role of calcium in luteinizing hormone-induced progesterone and cyclic AMP production in granulosa cells of the hen ( $G$ allus domesticus). Gen. comp. Endocr. 62, 120-128.

Asem, E.K. \& Hertelendy, F. (1986b) Trifluoperazine inhibits progesterone and cyclic AMP production in granulosa cells of the hen (Gallus domesticus). Gen. comp. Endocr. 64, 107-111.

Asem, E.K. \& Hertelendy, F. (1987) Trifluoperazine inhibits ovarian mitochondrial side-chain cleavage enzyme activity in the absence of calcium. J. Steroid Biochem. 28, 353-355.

Asem, E.K., Molnar, M. \& Hertelendy, F. (1987) Luteinizing hormone-induced intracellular calcium mobilization in granulosa cells: comparison with forskolin and 8-bromo-adenosine 3',5'-monophosphate. Endocrinology 120, 853-859.

Asem, E.K. \& Tsang, B.K. (1989a) Phorbol ester inhibits luteinizing hormone-, forskolin-, and dibutyryl cyclic AMP-induced progesterone production in chicken granulosa cells. Can. J. Physiol. Pharmacol. 67, 122-125.

Carnegie, J.A. \& Tsang, B.K. (1984) The calciumcalmodulin system: participation in the regulation of steroidogenesis at different stages of granulosa cell differentiation. Biol. Reprod. 30, 515-522.

Chiou, C.Y. \& Malagodi, M.H. (1975) Studies on the mechanism of action of a new $\mathrm{Ca}^{2+}$ antagonist, 
8-(N,N-diethylamino)octyl 3,4,5-trimethoxybenzoate hydrochloride in smooth and skeletal muscles. Br. J. Pharmac. 53, 279-285.

Etches, R.J. \& Duke, C.E. (1984) Progesterone, androstenedione, and oestradiol content of theca and granulosa tissues of the four largest ovarian follicles during the ovulatory cycle of the hen (Gallus domesticus). J. Endocrinol. 103, 71-76.

Exton, J.H. (1988) Mechanisms of action of calciummobilizing agonists: some variations on a young theme. FASEB J. 2, 2670-2676.

Ghosh, T.K., Bian, J. \& Gill, D.L. (1990) Intracellular calcium release mediated by sphingosine derivatives generated in cells. Science, NY 248, 1653-1656.

Hinkle, P.M., Jackson, A.E., Thompson, T.M., Zavacki, A.M., Coppola, D.A. \& Bancroft, C. (1988) Calcium channel agonists and antagonists: effects of chronic treatment on pituitary prolactin synthesis and intracellular calcium. Molec. Endocrinol. 2 , $1132-1138$.

Ho, A.K., Thomas, T.P., Chik, C.L., Anderson, W.B. \& Klein, D.C. (1988) Protein kinase C: subcellular redistribution by increased $\mathrm{Ca}^{2+}$ influx. J. biol. Chem. 263, 9292-9297.

Johnson, A.L. (1990) Steroidogenesis, and actions of steroids in the hen ovary. In CRC Critical Review's in Poultry Biology, Vol. 2, pp. 319-346. Ed. R. R. Dietert. CRC Press, Boca Raton.

Johnson, A.L. \& Tilly, J.L. (1990) Arachidonic acid inhibits luteinizing hormone-stimulated progesterone production in hen granulosa cells. Biol. Reprod. 42, $458-464$.

Johnson, A.L., Tilly, J.L. \& Levorse, J.M. (199!) Possible role for arachidonic acid in the control of steroidogenesis in hen theca. Biol. Reprod. 44, 338344.

Marrone, B.L. \& Asem, E.K. (1988) Cyclic adenosine monophosphate (cAMP) production in avian theca cells during follicular maturation. J. Reprod. Fert. 83, $67-71$.

Marrone, B.L. \& Hertelendy, F. (1985) Decreased androstenedione production with increased follicular maturation in theca cells from the dom- estic hen (Gallus domesticus). J. Reprod. Fert. 74, 543-550.

Onagbesan, O.M. \& Peddie, M.J. (1989) Calciumdependent stimulation of estrogen secretion by FSH from theca cells of the domestic hen (Gallus domesticus). Gen. comp. Endocr. 75, 177-186.

Putney, J.W., Takemura, H., Hughes, A.R., Horstman, D.A. \& Thastrup, O. (1989) How do inositol phosphates regulate calcium signaling? FASEB J. 3, 1899-1905.

Robinson, F.E. \& Etches, R.J. (1986) Ovarian steroidogenesis during follicular maturation in the domestic fowl (Gallus domesticus). Biol. Reprod. 35, 1096-1105.

Tilly, J.L. \& Johnson, A.L. (1988) Attenuation of hen granulosa cell steroidogenesis by a phorbol ester and 1-oleoyl-2-acetylglycerol. Biol. Reprod. 39, 1-8.

Tilly, J.L. \& Johnson, A.L. (1989a) Mechanisms by which a phorbol ester and a diacylglycerol analog inhibit hen granulosa cell steroidogenesis. Dom. Anim. Endocr. 6, 155-166.

Tilly, J.L. \& Johnson, A.L. (1989b) Regulation of androstenedione production by adenosine $3^{\prime}, 5^{\prime}$ monophosphate and phorbol myristate acetate in ovarian thecal cells of the domestic hen. Endocrinology 125, 1691-1699.

Tsang, B.K., Mattice, D.F., Li, M. \& Asem, E.K. (1989) Influence of A23187 and dibutyryl cyclic AMP on progestagen production by rat granulosa cells in vitro. J. Reprod. Fert. 86, 373-381.

Van Belle, H. (1981) R 24 571: a potent inhibitor of calmodulin-activated enzymes. Cell Calcium 2, $483-494$.

Veldhuis, J.D., Klase, P.A., Demers, L.J. \& Chafouleas, J.D. (1984) Mechanisms subserving calcium's modulation of luteinizing hormone action in isolated swine granulosa cells. Endocrinology 114, 441-449.

White, B.A., Power, E. \& Fay, F.S. (1989) Calcium regulation of prolactin gene expression: opposing effects of extracellular $\mathrm{CaCl}_{2}$ and $\mathrm{Ca}^{2+}$ ionophores. Molec. Endocrinol. 13, 1757-1764.

Received 31 July 1990 